DOI: 10.19085/journal.sijbpg021001

\title{
Political imprints on business scalability and planning
}

Amanda Jermy

University of Pennsylvania, Philadelphia, PA 19104, USA.

OScholedge International Journal of Business Policy \& Governance (ISSN 2394-3351), Vol.02, Issue 10 (2015) p1-8. Published by: Scholedge R\&D Center [www.theSCHOLEDGE.org] [Email:sijbpg@scholedge.org]

\section{Abstract}

The business community like other communities also depends on the general state of affairs of any state. The state is governed by the administration of political bodies. Thus, political environment directly affects the business policies and the execution thereof as far as the scalability and development of the business set up is concerned. Political environment like other segments of the business environment has its own considerations for the business leaders and planners. What would be the acceptability level of the intended products and services, this all depends on the general interference of the political inputs for the business community. Through this paper, it has been intended to put light on the political interferences in the business planning process across political structures and regimes. How a political set is critical for the performance or scope of the business process in a given geography. The geo-coverage of the paper should be taken as general as no specific reference is made to any political structure of any particular state.

Keywords: Political environment; Business environment, Business planning, Business strategy, Business effectiveness and performance.

\section{Introduction}

There are numerous outside ecological elements that can influence your business. It is regular for chiefs to evaluate each of these variables nearly. The point is dependably to take better choices for the association's advancement. Some basic variables are political, monetary, social and innovative (known as PEST investigation). Organizations additionally contemplate ecological, lawful, moral and demographical variables.

The political variables influencing business are frequently given a great deal of significance. A few parts of government arrangement can influence business. All organizations must take after the law. Supervisors must discover how up and coming enactments can influence their exercises.

The political environment can affect business associations from numerous points of view. It could include a danger component and lead to a noteworthy misfortune. You ought to comprehend that the political components have the ability to change results. It can likewise 
influence government strategies at neighborhood to elected level. Organizations ought to be prepared to manage the neighborhood and worldwide results of legislative issues.

Political patterns can affect any level of society, whether people, families or associations, for example, little organizations. Patterns in approaches set by government organizations and pioneers can influence the legitimate system inside which little organizations work, the economic situations that influence shopper conduct and the measure of help offered to little organizations by the administration. Monitoring political patterns at the national and neighborhood level is a vital piece of arranging and system advancement for your little business.

\section{Monetary Trends}

Diverse political gatherings or people institute distinctive approaches to guide national and neighborhood economies to success, in light of their own financial philosophies. This implies political patterns can affect charges required on organizations and people, leaving your clients and yourself with pretty much cash to spend in the commercial center. Financial approaches can likewise impact loan costs all through the economy, including rates for little business credits. The estimation of every single financial on-screen character in the public arena can be influenced by the administration's capacity to control monetary conditions. For instance, in a battling economy, shoppers may spend less in the commercial center, making banks offer less and littler credits to organizations.

\section{National Security}

National-security concerns can affect customers' purchasing and sparing propensities all through the economy, and patterns in legislative issues can do much to elevate or quiet security fears. The general population and gatherings in force whenever have an immediate impact over the connections of a country with its neighbors in the worldwide group, including threatening adversaries. A country settled can urge individuals to spend more by and large, as well as to put more in long haul resources, for example, homes and organizations.

\section{The Perils of Political Instability and Uncertainty}

In the event that there is one thing that business pioneers and business people loathe that is shakiness in the large scale environment. Organizations work as per gauges and situations about the future that include shocks and in addition surenesses. Then again, as much as organizations component in vulnerability, the one thing that needs to stay away from no matter what is the unsteadiness in the full scale environment that outcomes from political gridlock, radicalism, and political brokenness. This is the motivation behind why numerous 
developing markets in Asia and Africa either draw in or repulse outside speculators. Case in point, up to this point, African nations were evaded due to the common war like circumstance there while some Asian nations were correspondingly stayed away from by organizations on account of the political instability because of continuous administration changes and even upsets. As the instance of India and China, which we might talk about in point of interest in the following area, show, organizations herd to areas and states where there is political solidness. Further, organizations like to work in a situation that is not defaced by successive strikes, social turmoil, and disarray as their operations would be hit unfavorably because of these components.

\section{Why Businesses Like a Stable Macro Environment}

The explanations behind organizations favoring political steadiness is that once they get the grants and the licenses to work in districts and states, they put a considerable measure of cash in setting up offices. Further, notwithstanding amid the procedure of procuring area and different resources, they require the participation of the administration to encourage the same. Aside from this, political precariousness harms them as their representatives are regularly compelled to skip work on account of strikes and different dissents and this effects the benefits of the organizations adversely. Besides, organizations like a district that is neighborly and inviting towards them and not an antagonistic and threatening agreement. The point here is that political insecurity damages everything from benefits to operations to the working states of the representatives and subsequently, organizations maintain a strategic distance from it. The other perspective about political flimsiness is that key laws and regulations are frequently stuck in the lawmaking bodies and the parliaments and key endorsements are buried in bureaucratic postponements. Every one of these components scheme to make a circumstance that is not helpful for organizations. At long last, it is surely the case that capital is nation visually impaired and area dazzle and relocates and streams to wherever it is welcome and wherever the full scale circumstance is helpful. This is the lesson that government officials of all tones must comprehend in the event that they are to build up their voting demographics.

Changes in the administration strategy make up the political elements. The change can be financial, lawful or social. It could likewise be a blend of these elements.

Expand or diminish in duty could be a case of a political component. Your administration may expand charges for a few organizations and lower it for others. The choice will directly affect your organizations. In this way, you should dependably stay up and coming with such political variables. Government mediations like movements in financing cost can affect the interest examples of organization. 
- Certain variables make Inter-linkages from various perspectives. A few cases are:

- Political choices influence the financial environment.

- Political choices impact the nation's socio-social environment.

- Lawmakers can impact the rate of development of new innovations.

- Lawmakers can impact acknowledgment of new advances.

The political environment is maybe among the slightest unsurprising components in the business environment. A recurrent political environment creates, as majority rule governments need to seek after re-decision at regular intervals. This outside component of business incorporates the impacts of weight gatherings. Weight gatherings tend to change government strategies.

As political frameworks in distinctive zones fluctuate, the political effect contrasts. The nation's populace justly chooses open government framework. In totalitarian frameworks, government's energy gets from a select gathering.

Defilement is a boundary to monetary improvement for some nations. A few firms survive and develop by offering fixes to government authorities. The achievement and development of these organizations are not in view of the worth they offer to buyers.

The following, is a rundown of political variables influencing business:

- Organization

- Debasement level

- Opportunity of the press

- Taxes

- Exchange control

- Instruction Law

- Hostile to trust law

- Livelihood law

- Separation law

- Information insurance law

- Natural Law

- Wellbeing and security law

- Rivalry regulation

- Regulation and deregulation

- Charge arrangement (duty rates and motivating forces)

- Government soundness and related changes

- Government association in exchange unions and understandings 
- Import limitations on quality and amount of item

- Licensed innovation law (Copyright, licenses)

- Customer insurance and e-trade

- Laws that control environment contamination

There are 4 fundamental impacts of these political elements on business associations. They are:

- Sway on economy

- Changes in regulation

- Political dependability

- Alleviation of danger

\section{Sway on economy}

The political circumstance of a nation influences its financial setting. The monetary environment influences the business execution.

For instance, there are significant contrasts in Democratic and Republican strategies in the US. This impacts components like expenses and government spending, which eventually influence the economy. A more noteworthy level of government burning through regularly fortifies the economy.

\section{Changes in regulation}

Governments could change their standards and regulations. This could thus affect a business.

After the bookkeeping outrages of the mid 21st century, the US SEC turned out to be more mindful on corporate consistence. The administration presented the Sarbanes-Oxley consistence regulations of 2002. This was a response to the social environment. The social environment asked a change to make open organizations more at risk.

\section{Political stability}

Absence of political soundness in a nation impacts business operations. This is particularly valid for the organizations which work universally.

For instance, a forceful takeover could oust an administration. This could prompt mobs, plundering and general issue in nature. These disturb business operations. Sri Lanka was in a comparative state amid a common war. Egypt and Syria confronted aggravations as well. 


\section{Moderation of risk}

Purchasing political danger protection is an approach to oversee political danger. Organizations that have universal operations utilize such protection to decrease their danger presentation.

There are some lists that give a thought of the danger introduction in specific nations. The file of monetary opportunity is a decent sample. It positions nations in view of how governmental issues sways business choices there.

The importance of observing the political environment

Firms ought to track their political surroundings. Change in the political variables can influence business procedure due to the accompanying reasons:

- The strength of a political framework can influence the advance of a specific nearby market.

- Governments view business associations as a basic vehicle for social change.

- Governments pass enactment, which affects the relationship between the firm and its clients, suppliers, and different organizations.

- The administration is subject for ensuring general society interest.

- Government activities impact the financial environment.

- Government is a noteworthy buyer of merchandise and administrations.

\section{Conclusion}

The political environment in a nation influences its financial surroundings. The monetary environment, thusly, influences the execution of a business association. In the United States, for occasion, there are critical contrasts in Democratic and Republican arrangements. This has suggestions for elements, for example, duties and government spending, which thusly influence the nation's economy. A larger amount of government burning through has a tendency to fortify the economy, for case. One approach to oversee political danger is to purchase political danger protection. Associations that have worldwide operations utilize this sort of protection to moderate their danger introduction as a consequence of political flimsiness. There are lists that give a thought of the danger presentation an association has in specific nations. Case in point, a list of financial flexibility positions nations in light of how political impedance sways business choices in every nation. Evaluate the fundamental components of the business atmosphere, for example, corporate duty rate and the administration's appreciation for property rights. These components can be difficult to rely on in an insecure domain, yet they are keys to the reasonability of your business in the long haul, and in the event that you are going to put a decent arrangement of cash in another 
region, you need to make certain of however much as could reasonably be expected. In some cases it doesn't even make a difference regardless of whether the legislature is master business, inasmuch as there is the potential for benefit and the approaches of that administration are predictable. Things get to be tricky when political shakiness is combined with political savagery. It will be extremely hard to maintain business operations if there is thoughtful distress, terrorism or full scale war.

\section{References}

Aplin, J. C., \& Hegarty, W. H. (1980). Political influence: Strategies employed by organizations to impact legislation in business and economic matters. Academy of management journal, 23(3), 438-450.

Bergara, M., Henisz, W. J., \& Spiller, P. T. (1998). Political institutions and electric utility investment: A cross-nation analysis. California management review, 40, 18-35.

Brüderl, J., Preisendörfer, P., \& Ziegler, R. (1992). Survival chances of newly founded business organizations. American sociological review, 227-242.

Fitzpatrick, M. (1983). The definition and assessment of political risk in international business: A review of the literature. Academy of Management Review, 8(2), 249-254.

Frynas, J. G., Mellahi, K., \& Pigman, G. A. (2006). First mover advantages in international business and firm-specific political resources. Strategic Management Journal, 27(4), 321-345.

Keim, G., \& Baysinger, B. (1988). The efficacy of business political activity: Competitive considerations in a principal-agent context. Journal of Management, 14(2), 163-180.

Kessel, J. H. (1962). Governmental Structure and Political Environment: A Statistical Note about American Cities. American Political Science Review, 56(03), 615-620.

Kobrin, S. J. (1979). Political risk: A review and reconsideration. Journal of International Business Studies, 67-80.

March, J. G. (1962). The business firm as a political coalition. The Journal of politics, 24(04), 662-678.

Markus, G. B. (1979). The political environment and the dynamics of public attitudes: A panel study. American Journal of Political Science, 338-359.

Nicholson, S. P. (2003). The political environment and ballot proposition awareness. American Journal of Political Science, 47(3), 403-410. 
Orssatto, R. J., \& Clegg, S. R. (1999). The Political Ecology of Organizations Toward a Framework for Analyzing Business-Environment Relationships. Organization \& Environment, 12(3), 263-279.

Vogel, D. J. (1996). The study of business and politics. California Management Review, 38(3), 146.

Vormedal, I., \& Ruud, A. (2009). Sustainability reporting in Norway-an assessment of performance in the context of legal demands and socio-political drivers. Business Strategy and the Environment, 18(4), 207-222. 